\section{Sindrom sagorijevanja na poslu specijalizanata porodične medicine}

\begin{abstract}
APSTRAKT
Cilj istraživanja je bio da se ispita prevalenca sindroma sagorijevanja na poslu kod ljekara na specijalizaciji iz porodične medicine u Republici Srpskoj u odnosu na pol, bračni status i broj djece. Istraživanje je provedeno anketiranjem ljekara na specijalizaciji iz porodične medicine u edukativnim centrima porodične medicine Banja Luka i Doboj u periodu od 1. februara do 30. aprila 2010. godine. Ispitanici su popunjavali anketni upitnik za samoprocjenu nivoa stresa i 'Maslach Burnout Inventory' koji su bili dopunjeni podacima o dobi, polu, bračnom stanju i broju djece sa kojima žive. Istraživanjem je obuhvaćeno 57 ljekara, od kojih je bilo 20 muškaraca. Visok nivo stresa imalo je $77.2 \%$ ljekara. Ispitanici su imali umjeren nivo emocionalne iscrpljenosti i depersonalizacije. Kod ljekara-žena, izražen je umjeren, a kod ljekaramuškaraca niži nivo ličnog zadovoljstva; ali među ovim grupama ispitanika nije nađena statistički značajna razlika. Rezultati istraživanja nisu pokazali da postoji povezanost između pola, bračnog stanja, uključujući i broj djece u porodici, na pojavu sindroma sagorijevanja na poslu.
\end{abstract}

\section{KLJUČNE RIJEČI}

sindrom sagorijevanja na poslu, specijalizanti, bračno stanje, djeca u porodici

(Scr Med 2011;42:14-7)
Kosana Stanetić ${ }^{1,}$ Gordana Tešanović ${ }^{1}$, Marija BurgićRadmanović ${ }^{2}$

${ }^{1}$ Dom zdravlja Banja Luka, Katedra porodične medicine, Medicinski fakultet, 7800 o Banja Luka ${ }^{2}$ Klinika za psihijatriju, Klinički centar Banja Luka, $7800 o$ Banja Luka

\section{Kontakt osoba:}

Dr Kosana Stanetić

Tel: 051211177

Mob. Tel: 065535790

Email:mirkos@inecco.net

Submitted: February 10, 2011

Accepted: April 22, 2011
Sindrom sagorijevanja na poslu (eng. "burnout syndrome") je odgovor na dugotrajne hronične emocionalne i međuljudske stresore koji su povezani sa radnim mjestom. Prema definiciji koju su 1996. godine postavili Girdiano, Everly i Dusek ${ }^{1}$, sindrom sagorijevanja na poslu je stanje dugotrajne psihičke, fizičke i emocionalne iscrpljenosti uzrokovane pretjeranim i prolongiranim stresom. Neusaglašenost odnosa zaposlenih ljudi sa jedne i radne sredine sa druge strane mogu dovesti do ovog poremećaja koji se definiše kao hronični radni stres u koji su uključeni: osjećaj emocionalne iscrpljenosti, depersonalizacija i osjećaj smanjenog ličnog zadovoljstva. Sindrom se najčešće javlja kod osoba koje rade u direktnom kontaktu sa drugim ljudima, ${ }^{2-4}$ a ljekari su jedna od profesija s najvećim rizikom. ${ }^{5,6}$

Brojna su istraživanja o zastupljenosti sindroma sagorijevanja na poslu kod ljekara na specijalizaciji. Tako je pokazano $^{7}$ da je sindrom prisutan kod oko 50\% ljekara na specijalizaciji u SAD; najviše je bio zastupljen kod ljekara na specijalizaciji iz ginekologije i akušerstva (75\%), a najmanje kod ljekara na specijalizaciji iz porodične medicine (27\%). Studija provedena u Grčkoj na 311 specijalizanata pokazala je da umjerene i teške simptome sindroma sa- gorijevanja na poslu ima 154 (49.5\%) ispitanika. ${ }^{8}$ Nezadovoljsvo sistemom specijalizacije glavni je uzrok visoke prevalence ovog sindroma u pomenutom istraživanju. Brojna istraživanja o prisustvu i uzrocima sindroma sagorijevanja na poslu kod ljekara na specijalizaciji koja su provedena od 1983. do 2004. godine pokazuju da intenzivan rad, nedostatak vremena za odmor i socijalne kontakte van posla predstavljaju najvažnije predisponirajuće faktore za razvoj ovog sindroma kod ljekara na specijalizaciji. ${ }^{9}$

Cilj ovog istraživanja je bio da se ispita prevalenca sindroma sagorijevanja na poslu kod ljekara na specijalizaciji iz porodične medicine u Republici Srpskoj u odnosu na pol, bračni status i broj djece sa kojima ispitanici žive.

\section{Metode}

Istraživanje je provedeno anketiranjem ljekara na specijalizaciji iz porodične medicine u edukativnim centrima porodične medicine Banja Luka i Doboj u periodu od 1. februara do 30. aprila 2010. godine. Ljekarima koji su u to vrijeme bili na specijalizaciji iz porodične medicine ponuđen je anketni upitnik koji je sadržavao pitanja koja su formulisana prema poznatim upitnicima za samoprocjenu 
nivoa stresa ${ }^{1}$ i Maslach Burnout Inventory. ${ }^{6}$ Naš upitnik je dopunjen podacima o dobi, polu, bračnom statusu i broju djece sa kojima ispitanici žive. Anketa je bila anonimna, a ispitanici su samostalno popunjavali anketni upitnik.

Za statističku analizu korišteni su $t$-test ili $\chi^{2}$ test, a nivo značajnosti je bio $\mathrm{p}<0.05$.

Mjerenja. Upitnik za samoprocjenu nivoa stresa sadrži deset pitanja. Maksimalan broj bodova je 40, a ispitanici koji imaju između 25 i 40 bodova su stanju visokog nivoa stresa. Anketni upitnik Maslach Burnout Inventory sadrži 22 pitanja na koja su odgovori bodovani Likertovom skalom od o do 6 da se odrede ove psihičke dimenzije: emocionalna iscrpljenost (EI), depersonalizacija (DP) i lično zadovoljstvo (LZ). EI se procjenjuje odgovorima na 9 pitanja, a maksimalan broj bodova je 54 (zbir bodova $<17$ pokazuje nizak, 18-29 umjeren, >30 visok nivo emocionalne iscrpljenosti). DP se testira pomoću 5 pitanja, a maksimalan broj bodova je 30 (zbir bodova $<5$ pokazuje nizak, 6-11 umjeren, $>12$ visok nivo depersonalizacije), a LZ se procjenjuje na osnovu odgovora na 8 pitanja; maksimalan broj bodova je 48 (zbir bodova <33 pokazuje visok, 34-39 umjeren, >40 nizak nivo ličnog zadovoljstva).

\section{Rezultati}

Od 69 distribuiranih anketnih upitnika popunjeno je i analizirano 57; 20 (35.1\%) muškog i 37 (64.9 \%) ženskog pola. Prosječna starost anketiranih ljekara bila je 37.3 (SD=6.94). Najmlađi ispitanik imao je 27, a najstariji 55 godina. U grupi anketiranih ljekara bilo je 34 oženjenih/ udatih. Bez djece je bilo 24, a jedno ili više djece imalo je 33 anketirana ljekara.

Visok nivo stresa je ustanovljen kod 44 (77.2\%) ispitanika (Tab. 1). Ljekari ženskog pola imali su viši nivo stresa od muških ispitanika (62.2\%, odnosno 55.0\%), ali ta razlika nije statistički signifikantna. Srednje vrijednosti emocionalne iscrpljenosti kod ljekara ženskog pola su bile 22.46 $(\mathrm{SD}=2.2)$, a kod ispitanika muškog pola $21.3(\mathrm{SD}=2.9)$. Ta razlika nije statistički signifikantana $(\mathrm{p}=0.702)$.
Nivo emocionalne iscrpljenosti, depersonalizacije i ličnog zadovoljstva kod ženskih i muških ispitanika je prikazan na Tabeli 1. Razlike među polovima nisu ni statistički ni klinički značajne.

Kod ljekara koji žive u braku, srednja vrijednost za emocionalnu iscrpljenost iznosila je 23.8 (SD=2.4), depersonalizaciju $7.8(\mathrm{SD}=1.1)$ i lično zadovoljstvo $39.6(\mathrm{SD}=1.1)$ bodova. Kod neoženjenih/neudatih srednja vrijednost emocionalne iscrpljenosti iznosila je $19.4(\mathrm{SD}=2.2)$ boda, a kod depersonalizacije 6.8 ( $\mathrm{SD}=1.0)$ i ličnog zadovoljstva $38.9(\mathrm{SD}=1.4)$ bodova. Ove razlike među ispitanicima koje se odnose na bračni status nisu statistički značajne.

Kod ispitanika koji nisu imali djecu nađene su srednje vrijednosti emocionalne iscrpljenosti 19.4 ( $\mathrm{SD}=2.1$ ), depersonalizacije $6.6(\mathrm{SD}=1.0)$ i ličnog zadovoljstva $39.1(\mathrm{SD}=1.4)$ bodova. Kod anketiranih ljekara koji su imali jedno dijete ili više djece te vrijednosti su iznosile za emocionalnu iscrpljenost 24.0 ( $\mathrm{SD}=2.5)$, depersonalizaciju 8.1 $(\mathrm{SD}=1.1)$ i lično zadovoljstvo $39.5(\mathrm{SD}=1.1)$. Ni jedna razlika tri psihičke dimenzije između ispitanika koji su imali djecu i onih bez djece nije bila statistički signifikantna.

\section{Diskusija}

Rezultati ovog istraživanja pokazuju da visok procenat (77.2\%) anketiranih ljekara na specijalizaciji ima visok nivo stresa. Anketirani ljekari oba pola imaju umjeren stepen emocionalne iscrpljenosti i depersonalizacije, dok ljekari ženskog pola imaju umjeren stepen, a ljekari muškog pola nesto niži stepen ličnog zadovoljstva.

U preglednom članku koji obuhvata više istraživanja o sindromu sagorijevanja na poslu kod ljekara na specijalizaciji ${ }^{9}$ nije ustanovljeno da postoji značajna razlika između ispitanika muškog i ženskog pola. Međutim, Geurtis i sar. ${ }^{10} \mathrm{su}$ ustanovili da ljekari ženskog pola imaju veći stepen emocionalne iscrpljenosti, dok u nivoima depersonalizacije među polovima nije bilo razlike.

Rezultati ostalih istraživanja pokazaju da su sociodemografska obilježja (pol, bračni status ili broj djece) povezani

Tabela 1. Nivo stresa, emocionalne iscrpljenosti, depersonalizacije i ličnog zadovoljstva kod ispitanika

\begin{tabular}{lll}
\hline & Muškarci & Žene \\
\hline Visok nivo stresa & $55.0 \%$ & $62.2 \%$ \\
\hline Emocionalna iscrpljenost & $21.3(\mathrm{SD}=2.89)^{*}$ & $22.5(\mathrm{SD}=2.17)$ \\
\hline Depersonalizacija & $7.5(\mathrm{SD}=1.35)$ & $7.4(\mathrm{SD}=1.18)$ \\
\hline Lično zadovoljstvo & $40.7(\mathrm{SD}=1.12)$ & $38.6(\mathrm{SD}=1.18)$ \\
\hline
\end{tabular}

*Srednja vrednost; SD-standardna devijacija. Među polovima nije nađena signifikantna razlika. 
sa pojavom sindroma sagorijevanja na poslu, a roditeljstvo se smatra kao protektivni faktor. ${ }^{11}$ Woodside i sar..$^{12}$ su ustanovili da specijalizanti ženskog pola imaju manje izražene simptome depersonalizacije $\mathrm{u}$ odnosu na specijalizante muškog pola, a da specijalizanti u čijim je porodicama bilo djece imaju niži stepen depersonalizacije i emocionalne iscrpljenosti. Međutim, kod specijalizanata porodične medicine u Zagrebu nije nađena značajna razlika između anketiranih u nekoj od subskala ovog sindroma u odnosu na njihova sociodemografska obilježja. ${ }^{13} \mathrm{Ni}$ istraživanje Martinija i saradnika ${ }^{14}$ nije pokazalo da roditeljstvo utiče na pojavu sindroma sagorijevanja na poslu kod ljekara na specijalizaciji iz porodične medicine, ali je Lemkau ${ }^{15}$ ustanovio da roditeljstvo dovodi do nižeg stepena depersonalizacije. U našem istraživanju nije nađena povezanost između stepena sindroma sagorijevanja na poslu u odnosu na pol, bračni status i roditeljstvo u bilo kojoj podskali sindroma.

Naporan program specijalizacije, pripremeza specijalistički ispit, odvajanje od porodice, promjena životne i radne sredine za vrijeme specijalizacije i lična finansijska situacija vjerovatno su uzrok visokog nivoa stresa i simptoma sindroma sagorijevanja na poslu kod ljekara specijalizanata porodicne medicine. Prosječna starost specijalizanata u našem istraživanju je preko 37 godina, što ukazuje da bi i godine mogle biti uzrok težem podnošenju obaveza specijalizacije. Zato bi vrijedilo detaljnije istražiti uticaj svih pomenutih faktora na sagorijevanje na poslu, a možda i one faktore koji se odnose na specificne društveno-ekonomske prilike u regionu koje su nastale u vrijeme nedavnog rata i tokom poslijeratnog perioda.

Samopomoć i briga o sebi nije dio profesionalne edukacije ljekara i uglavnom zauzima veoma nisko mjesto na listi prioriteta ljekara-specijalizanata. U Švajcarskoj 21\% ljekara u primarnoj zdravstvenoj zaštiti nema svog porodičnog ljekara, a $90 \%$ vrši samoliječenje. ${ }^{16} \mathrm{U}$ istraživanju Kumbrije i saradnika čak $62.9 \%$ ljekara porodične medicine u Hrvatskoj nije imalo svog izabranog ljekara već se liječilo samostalno. ${ }^{17} \mathrm{U}$ svom poslu ljekari se bave problemima drugih ljudi po cijeli dan, tako da imaju malo vremena za rješavanje svojih vlastitih problema. ${ }^{5}$ Rezultati našeg, ali i drugih istraživanja ukazuju na potrebu edukacije ljekara na specijalizaciji o prevenciji i metodama za prevazilaženje stresa i sindroma sagorijevanja na poslu.

Autori ovog članka nisu deklarisali konflikt interesa u vezi s ovim istraživanjem.

\section{Reference}

1. Girdin DA, Everly GS, Dusek DE. Controlling stress and tension. Needham Heights, Allyn and Bacon,1996.

2. Michaels RM. Physician burnout. Pennsyl Med 1996; 99:18-21.

3. Maslach C, Schaufeli W, Leiter MP. Job burnout. Ann Rev Psychol 2001; 52: 397-422.

4. Peterson U. Stress and burnout in healthcare workers. Stockholm, Karolinska Institutet, 2008.

5. Guderson L. Physician burnout. Anal Int Med 2001; 135:145-8.

6. Maslach C, Jackson SE, Leiter MP. MBI: The Maslach burnout inventory: Manual. Palo Alto, Consulting Psychologists Press, 1996.

7. Martini S, Arfken CI, Churchill A, Balon R. Burnout comparison among residents in different medical specialties. Acad Psychiatry 2004; 28:240-2.

8. Msaouel P, Keramaris NC, Tasoulis A, Kolokythas D, Syrmos N, Pararas E, Thireos E, Lionis C. Burnout and training satisfaction of medical residents in Greece: will the European work time directive make a difference? Hum Resour Health 2010. Published online doi:10.1186/1478-4491-8-16.

9. Thomas NK. Resident burnout. JAMA 2004;292:2880-9.

10. Geurts S, Rutte C, Peeters M. Antecedents and consequences of work-home interference among medical residents. Soc Sci Med 1999;48:1135-48.

11. European General Practice Research Network Burnout Study Group. Burnout in European family doctors: the EPGRN study. Fam Pract 2008;25:245-65.

12. Woodside JR, Miller MN, Floyd MR, McGowen KR, Pfortmiller DT. Observation on burnout in family medicine and psychiatry residents. Acad Psychiatry 2008;32:13-9.

13. Tušek S, Ožvačić Z, Polašek O, Katić M. Izloženost specijalizanata obiteljske medicine sindromu izgaranja na poslu. Med Fam Croat 2010;2:8-17.

14. Martini S, Arfken CL, Churchill A, et al. Burnout comparison among residents in different medical specialities. Acad Psychiatry 2004; 28:240-2.

15. Lemkau J, Rafferty J, Gordon RJ. Burnout and career-choice regent among family practice physicians in early practice. Fam Pract Res J 1994; 14:213-22.

16. Schneider M, Bouvier Gallacchi M, Goehring C, et al. Personal use of medical care and drugs among Swiss primary care physicians. Swiss Med Wkly 2007;137:121-6.

17. Kumbrija S, Blažeković-Milaković S, Doko-Jelinić J, et al. Zdravstveni radnici-odnos prema vlastitom zdravlju. Acta Med Croatica 2007;61:105-10. 


\title{
Prevalence of Burnout Syndrome Among Family Medicine Residents
}

\author{
Kosana Stanetić, Gordana Tešanović, Marija Burgić-Radmanović
}

\begin{abstract}
A survey in the form of a questionnaire assessed the prevalence of the burnout syndrome among family medicine residents in the Republic of Srpska. The survey considered gender, marital status, and number of children in the family of participants. This study was based upon results of a survey questionnaire that was distributed to family medicine residents in the Educational Centers of Family Medicine, Banja Luka and Doboj, during the period from February 1 to April 30, 2010. Participants answered the self-assessment questionnaire regarding stress level and also the Maslach Burnout Inventory questionnaire that provided data regarding age, sex, marital status and the number of children in family. The respondents included 57 physicians, 20 male and 37 female, all of whom were residents in family practice. More than three fourths $(77.2 \%)$ of the respondents had a high level of stress. Furthermore, the residents had moderate levels of emotional exhaustion and depersonalization. Female residents reported only moderate levels of personal accomplishment, while male physicians had lower levels. There was no statistically significant difference between data from the male and female groups. The results of the survey failed to establish any correlation between gender, marital status, including the number of children per family, and the prevalence of the burnout syndrome.
\end{abstract}

\section{KEY WORDS}

burnout syndrome, residents, marital status, number of children per family. 